\title{
Patterns of differential digestion of bacteria in deposit feeders: a test of resource partitioning
}

\author{
Craig J. Plante ${ }^{1, *}$, April G. Shriver ${ }^{2}$ \\ ${ }^{1}$ Department of Biology, Grice Marine Biological Laboratory, University of Charleston, 205 Fort Johnson, Charleston, \\ South Carolina 29412, USA \\ ${ }^{2}$ Department of Zoology and Physiology, Louisiana State University, Baton Rouge, Louisiana 70803, USA
}

\begin{abstract}
Diverse strains of bacteria vary in their susceptibilities to lysis by the digestive fluids of deposit-feeding invertebrates. Thus, sedimentary bacterial communities are influenced both qualitatively and quantitatively with gut passage. We tested the hypothesis that the rank order of lytic susceptibility of bacterial strains is consistent for an array of deposit feeders. A turbidimetric assay was used to test the lytic susceptibility of logarithmic phase cultures of 10 environmental isolates to the digestive fluids of 6 deposit feeders from diverse taxa. Lysis varied significantly among bacterial strains $(p=0.0002)$ and among deposit feeders from which digestive fluids were taken $(p=0.0258)$. Using rank correlation, we rejected the null hypothesis of independence among susceptibility trends. Particular bacterial strains were resistant to digestion, regardless of the deposit-feeding consumer, while the remaining strains showed fairly consistent patterns in their relative susceptibilities. At least qualitatively, models constructed to predict microbial community responses to gut passage, based on experiments with model organisms, should be applicable to diverse deposit-feeding taxa.
\end{abstract}

KEY WORDS: Sedimentary bacteria - Deposit feeder - Benthic microbial loop - Trophic interactions

\section{INTRODUCTION}

Sedimentary bacteria are the chief decomposers in marine ecosystems; their activities largely determine rates of nutrient cycling. However, little predictive ability yet exists regarding the ecology of bacteria in sediments, particularly in terms of species composition. One of many remaining questions regarding the ecology of sedimentary bacteria is that of the sources of removal; i.e. what is the fate of the high (relative to identified removal processes) bacterial production that is measured in sediments (see Kemp 1990, Epstein 1997 for reviews)?

The abundance of sediment-feeding invertebrates (i.e. deposit feeders), coupled with their high rates of sediment processing, suggests a potentially important role as grazers of bacteria. Indeed, bacterial numbers do decline with gut passage, yet a large fraction survive this digestive gantlet. It has become clear that bacterial species differ in their resistance to digestion

•E-mail: plantec@cofc.edu within the gut of a particular deposit feeder (e.g. Dobbs \& Guckert 1988, Duchene et al. 1988, Plante \& Shriver 1998). It is also apparent that bacteriolytic capacity varies quantitatively among diverse deposit-feeding taxa (Plante \& Mayer 1994).

Resource partitioning among the microbial components of the diet of benthic meiofauna has been demonstrated (e.g. Gray \& Johnson 1970, Carman \& Thistle 1985). To our knowledge, no such study has been performed to determine whether deposit-feeding macro- and megafauna likewise 'partition' bacterial resources. This is perhaps due to the widely held idea that sedimentary bacteria can only rarely play a major role in satisfying the nutritional needs of deposit feeders (e.g. Plante et al. 1989, Kemp 1990, Grossmann \& Reichardt 1991). The question, however, remains important from the perspective of the bacterium-and the microbial ecologist-regardless of whether digestion of bacteria sustains the animal.

On the other hand, some taxonomic groups of bacteria seem to fare well with gut throughput (e.g. vibrios; Duchene et al. 1988, Prieur et al. 1990) as compared to 
Table 1. Biochemical and physiological characteristics of environmental isolates used in this study. Morph $=$ cell morphology $(\mathrm{r}=$ rods, $\mathrm{cb}=$ coccobacilli, $\mathrm{c}=$ cocci), $0 \% \mathrm{NaCl}=$ growth in $0 \% \mathrm{NaCl}, 4 \% \mathrm{NaCl}=$ growth in $4 \% \mathrm{NaCl}, 37^{\circ} \mathrm{C}=$ growth at $37^{\circ} \mathrm{C}, \mathrm{MOT}$ $=$ motility, $\mathrm{OXI}=$ oxidase production, $\mathrm{O}_{2} \mathrm{REL}=\mathrm{O}_{2}$ relationship $(\mathrm{A}=$ aerobe, $\mathrm{F}=$ facultative anaerobe, $\mathrm{AN}=$ anaerobe $), \mathrm{O} / \mathrm{F}=\mathrm{Oxi}-$ dation/fermentation, TCBS = growth on TCBS agar, $\mathrm{GS}=$ gram stain, $\mathrm{NO}_{3}=$ nitrate reduction, $\mathrm{TRP}=$ tryptophanase, $\mathrm{ADH}=\mathrm{argi}-$ nine dihydrolase, URE = urease, ESC = esculin hydrolysis, GEL = gelatinase, PNPG = $\beta$-galactosidase, GLUa =D-glucose assimilation, $\mathrm{ARAa}=$ arabinose assimilation, $\mathrm{MNEa}=\mathrm{D}$-mannose assimilation, $\mathrm{MANa}=\mathrm{D}$-mannitol assimilation, $\mathrm{NAGa}=$ $\mathrm{N}$-acetyl-D-glucosamine assimilation, MALa $=$ maltose assimilation, GNTa $=$ D-gluconic acid assimilation, CAPa $=$ capric acid assimilation, $\mathrm{ADIa}=$ adipic acid assimilation, $\mathrm{MLTa}=\mathrm{L}$-malic acid assimilation, CITa $=$ citric acid assimilation, $\mathrm{PACa}=$ phenylacetic acid assimilation. $v=$ variable, $w=$ weak

\begin{tabular}{|c|c|c|c|c|c|c|c|c|c|c|c|c|c|c|c|}
\hline Strain & Morph & $\begin{array}{c}0 \% \\
\mathrm{NaCl}\end{array}$ & $\begin{array}{c}4 \% \\
\mathrm{NaCl}\end{array}$ & $37^{\circ} \mathrm{C}$ & MOT & OXI & $\begin{array}{c}\mathrm{O}_{2} \\
\mathrm{REL}\end{array}$ & $\mathrm{O} / \mathrm{F}$ & TCBS & GS & $\mathrm{NO}_{3}$ & TRP & $\mathrm{ADH}$ & URE & $\mathrm{ESC}$ \\
\hline SS-1 & $\mathrm{r}$ & - & + & - & + & + & $\mathrm{F}$ & o & - & - & - & - & + & + & + \\
\hline SS- 4 & $c b$ & - & + & $+(w)$ & + & + & $\mathrm{F}$ & 0 & - & - & - & - & + & + & + \\
\hline SS-9 & $r$ & + & + & + & - & + & $\mathrm{F}$ & $\mathrm{O} / \mathrm{F}$ & - & - & + & - & + & + & - \\
\hline SS-13 & $r$ & + & $+(w)$ & - & - & - & F & $\mathrm{O} / \mathrm{F}$ & + & + & + & - & + & + & + \\
\hline AP-1 & $\mathrm{r}$ & - & + & + & + & - & F & $\mathrm{O} / \mathrm{F}$ & - & + & - & - & + & + & + \\
\hline PI-2 & $\mathrm{r} / \mathrm{cb}$ & - & + & - & + & + & $\mathrm{F}$ & $\mathrm{O} / \mathrm{F}$ & - & - & + & - & + & + & - \\
\hline PI-9 & $\mathrm{C}$ & & + & - & + & + & $\mathrm{F}$ & 0 & - & - & - & - & + & + & + \\
\hline SS-111 & $1 \mathrm{cb}$ & - & + & - & + & + & $\mathrm{F}$ & $\mathrm{N}$ & - & - & $-(v)$ & - & - & + & + \\
\hline SS-116 & $5 \quad \mathrm{r}$ & - & $+(w)$ & - & - & - & $F$ & $\mathrm{O} / \mathrm{F}$ & + & - & + & - & + & + & - \\
\hline SS-118 & $8 \quad$ r & - & + & - & + & + & F & $\mathrm{N}$ & - & - & - & - & + & + & + \\
\hline Strain & GEL & PNPG & GLUa & ARAa & MNEa & MANa & NAGa & MALa & GNTa & $\mathrm{CAPa}$ & ADIa & MLTa & CITa & PACa & \\
\hline SS-1 & + & - & - & - & - & - & - & - & - & - & - & - & - & - & \\
\hline SS-4 & + & - & + & - & - & - & + & + & - & - & - & + & - & - & \\
\hline SS-9 & - & - & - & - & - & - & - & - & - & + & - & + & - & - & \\
\hline SS-13 & - & + & + & - & - & + & - & + & + & - & - & + & + & + & \\
\hline AP-1 & - & + & + & - & + & + & + & + & + & - & - & - & - & - & \\
\hline PI- 2 & + & + & - & + & - & - & - & + & + & - & - & - & - & - & \\
\hline PI-9 & + & + & + & - & - & + & + & + & + & - & - & + & + & - & \\
\hline SS-111 & $1+$ & - & + & + & + & + & + & + & + & - & + & + & + & + & \\
\hline SS-116 & $5 \quad-$ & - & + & - & + & - & - & - & + & - & + & + & + & + & \\
\hline SS-118 & $3+$ & - & + & + & + & + & + & + & + & + & + & + & + & + & \\
\hline
\end{tabular}

other groups. Also, there is some limited evidence that morphology or ultrastructure can be associated with greater resistance to digestion by aquatic metazoa. For instance, gram-positive bacteria may be more resistant than gram-negative bacteria (Reiper 1982, King et al. 1991, Plante \& Mayer 1994, Plante \& Shriver 1998).

Here we attempt to test whether the patterns of lytic susceptibility, i.e. the rank order of susceptibility among strains, are consistent across disparate species of deposit feeders.

\section{METHODS}

Specimen collection. Digestive fluids from 6 marine deposit feeders were assayed for bacteriolytic activity: Stereobalanus canadensis (Enteropneusta: Harrimanidae), Notomastus lobatus (Polychaeta: Capitellidae), Arenicola marina (Polychaeta: Arenicolidae), Microphiopholis gracillima (Ophiuroidea: Amphiuridae), Amphitrite ornata (Polychaeta: Terebellidae), and Leptosynapta tenuis (Holothuroidea: Synaptidae). Digestive fluids from each species were collected as described elsewhere (Plante \& Mayer 1994) and combined so as to make at least 3 distinct pools for each taxon. For a separate study, 43 different bacterial strains were isolated from surficial sediments and deposit-feeder feces (Plante \& Shriver 1998). Of these, 10 strains of diverse structure and physiology (Table 1) were used in the present study. Initial isolations were made at $21 \% \mathrm{O}_{2}$ on either Marine Broth 2216 (Difco) agar medium, or this same medium augmented with $\mathrm{NaCl}$ to produce a salinity of approximately $2 \times$ that of seawater $(70 \%)$. The high-salt medium was used to selectively inhibit a greater proportion of gram-negative bacteria, thus facilitating the isolation of more gram-positive strains. Each environmental isolate was tested for biochemical, physiological and morphological characteristics (Table 1). In addition to providing basic information for each strain, the results from these tests were used to eliminate redundant strains.

Lytic assays. Bacteriolytic assays were performed with gut extracts by methods previously described (Plante \& Mayer 1994). Bacteria were cultured in $40 \mathrm{ml}$ of filtered 2216 Marine Broth (Difco) and incubated on a shaker at $25^{\circ} \mathrm{C}$ for $16 \mathrm{~h}$. Polypropylene micro- 
centrifuge tubes were filled with $1.5 \mathrm{ml}$ of each mid- to late-log phase culture, then centrifuged at $20^{\circ} \mathrm{C}$ for $10 \mathrm{~min}$ at $5000 \mathrm{rpm}(\sim 1980 \times g)$ to pelletize cells. Pellets were then washed twice with filter-sterilized seawater and repelleted. Immediately prior to analysis, pellets were resuspended in $66 \mathrm{mM}$ phosphate buffer $(\mathrm{PB}$; potassium phosphate, monobasic, pH 6.2), then transferred to disposable $1 \mathrm{~cm}$ polystyrene cuvette tubes and further diluted to obtain absorbance values between 0.6 and 0.7 at $450 \mathrm{~nm}$. Each strain/deposit feeder combination was assayed in triplicate, with a distinct $40 \mathrm{ml}$ culture for each replicate. Following centrifugation $(-1980 \times g)$ to remove particulates, $5 \mu \mathrm{l}$ of undiluted gut fluid from different pools ( 3 for each deposit-feeding taxon) was added and mixed via pipet to 3 of the tubes. The spectrophotometer (Milton Roy Spectronic 601) was zeroed against $\mathrm{PB} ; 5 \mu \mathrm{l}$ of $\mathrm{PB}$ was added to 3 additional bacterial suspensions to serve as controls. Lysis was followed turbidimetrically with $\mathrm{A}_{450}$ readings taken at $0,15,30,45,60,120,180$, and $300 \mathrm{~s}$ for each bacterial strain. Lytic rates were calculated by using the linear portions of progress curves spanning at least $30 \mathrm{~s}$ and 3 absorbance readings. For each bacterial strain, a mean lytic rate for the PB control was calculated and subtracted from the gut-fluid rates.

Data analysis. Lytic rates were compared to rates obtained with additions of PB (controls) using the Mann-Whitney $U$-test $(n=3)$. Rates which did not differ significantly from these controls were converted to a value of zero. Kruskal-Wallis tests were used to determine whether bacteriolytic rates differed significantly among digestive fluid source (i.e. deposit-feeding species) and among bacterial strains. For each deposit feeder, resultant rates were ranked ( 1 = highest susceptibility). Pairwise tests of independence for the rank orders of lytic susceptibility were performed using rank correlation. A form of the equation modified for use with many ties was used to calculate Spearman's Rho:

$$
\rho=\frac{\sum_{i=1}^{n} \mathrm{R}\left(\mathrm{X}_{i}\right) \mathrm{R}\left(\mathrm{Y}_{1}\right)-n\left(\frac{n+1}{2}\right)^{2}}{\left(\sum_{i=1}^{n} \mathrm{R}\left(\mathrm{X}_{i}\right)^{2}-n\left(\frac{n+1}{2}\right)^{2}\right)^{\frac{1}{2}}\left(\sum_{i=1}^{n} \mathrm{R}\left(\mathrm{Y}_{i}\right)^{2}-n\left(\frac{n+1}{2}\right)^{2}\right)^{\frac{1}{2}}}
$$

\section{RESULTS}

Lytic susceptibility varied significantly among bacterial strains ( $p=0.0002$; Kruskal-Wallis) (Fig 1) and lytic rates differed for the various deposit feeders $(p=$ 0.0258 ; Kruskal-Wallis) by at least a factor of 10 (Fig 1). The strain SS-1 was generally the most susceptible, while AP-1, SS-9, SS-13 and SS-116 were resistant to digestion by the gut fluids of all 6 deposit feeders (Fig 1, Table 2).

In the majority of pairwise comparisons of rank order of lytic susceptibility, the null hypothesis of independence was rejected - that is, the patterns of susceptibility were similar for the various deposit feeders (Table 3). Most of those which could not be rejected were comparisons with Stereobalanus canadensis which had a high (9 of 10) number of non-significant lytic rates (and therefore ties). The additional exception involved the comparison between Notomastus lobatus and Leptosynapta tenuis, which trended toward significance but could not be rejected at $\alpha=$ 0.05 (Table 3 )

\section{DISCUSSION}

Our finding that the absolute rate of lysis was significantly different when bacteria were exposed to digestive agents from different deposit feeders is in agreement with the work of Plante \& Mayer (1994). They showed that the digestive capacities of 2 polychaetes

Table 2. Ranking of lytic susceptibility ( 1 = highest) of bacterial strains to the midgut flunds of 6 deposit feeders. Bacteriolytic rates which were not significantly different from the PB control were set to zero and resulted in ties for ranks

\begin{tabular}{|c|c|c|c|c|c|c|}
\hline $\begin{array}{l}\text { Bacteria } \\
\text { strain }\end{array}$ & $\begin{array}{l}\text { Arenicola } \\
\text { marina }\end{array}$ & $\begin{array}{c}\text { Notomastus } \\
\text { lobatus }\end{array}$ & $\begin{array}{c}\text { Microphiopholis } \\
\text { gracillima }\end{array}$ & $\begin{array}{l}\text { Amphitrite } \\
\text { ornata }\end{array}$ & $\begin{array}{c}\text { Leptosynapta } \\
\text { tenuis }\end{array}$ & $\begin{array}{c}\text { Stereobalanus } \\
\text { canadensis }\end{array}$ \\
\hline SS-1 & 1 & 5 & 1 & 1 & 1 & 1 \\
\hline SS-4 & 2 & 6 & 5 & 5 & 7 & 6 \\
\hline PI-9 & 3 & 1 & 2 & 4 & 3 & 6 \\
\hline SS-118 & 4 & 2 & 3 & 3 & 2 & 6 \\
\hline SS-111 & 5 & 3 & 4 & 2 & 7 & 6 \\
\hline PI-2 & 6 & 4 & 6 & 6 & 7 & 6 \\
\hline$A P-1$ & 8.5 & 7.5 & 8.5 & 8.5 & 7 & 6 \\
\hline SS-9 & 8.5 & 7.5 & 8.5 & 8.5 & 7 & 6 \\
\hline SS-13 & 8.5 & 7.5 & 8.5 & 8.5 & 7 & 6 \\
\hline SS-116 & 8.5 & 7.5 & 8.5 & 8.5 & 7 & 6 \\
\hline
\end{tabular}


a)

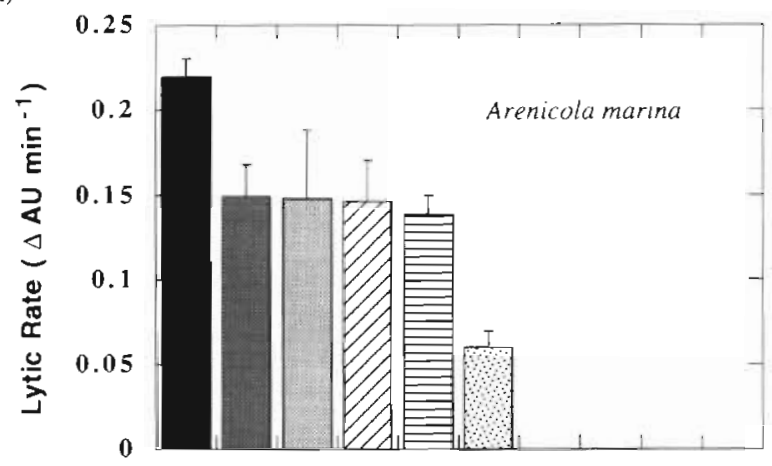

b)

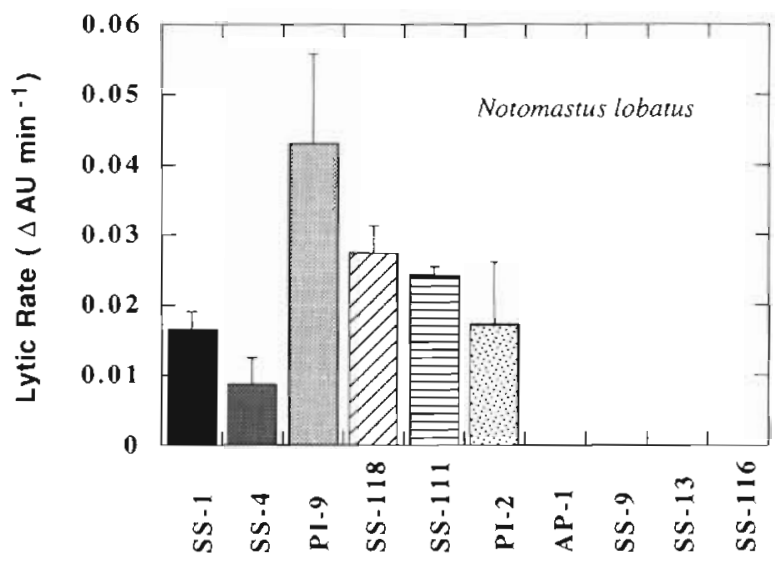

c)

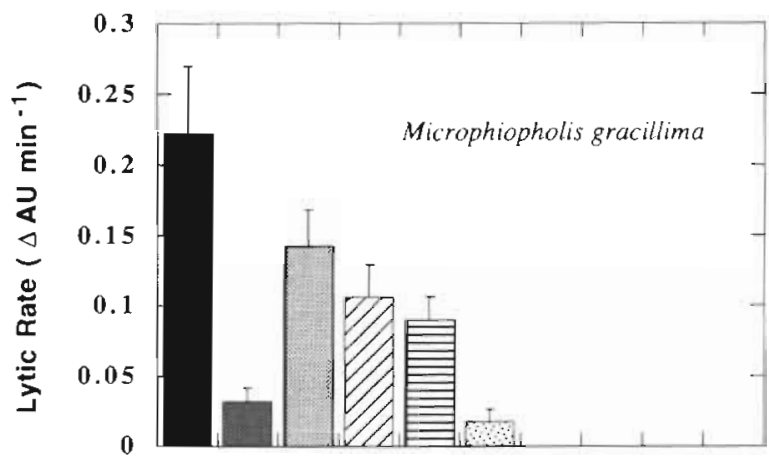

d)

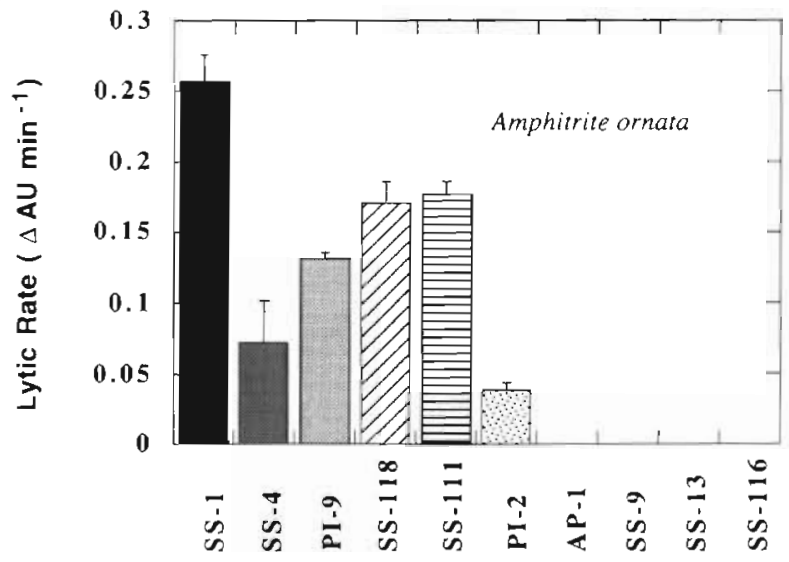

e)

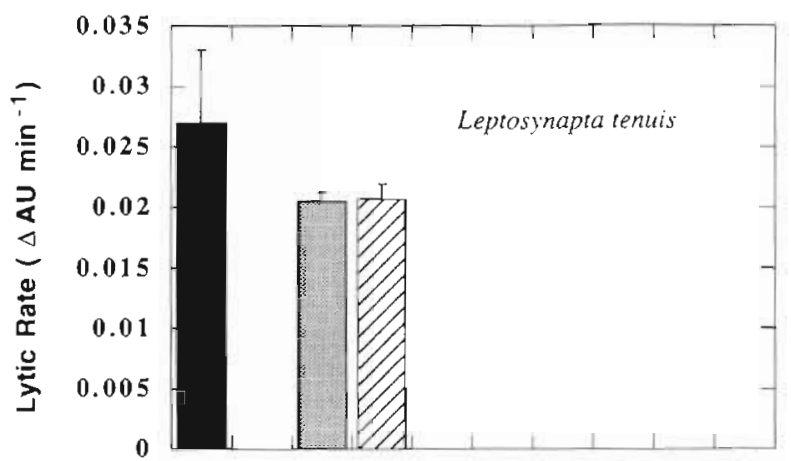

f)

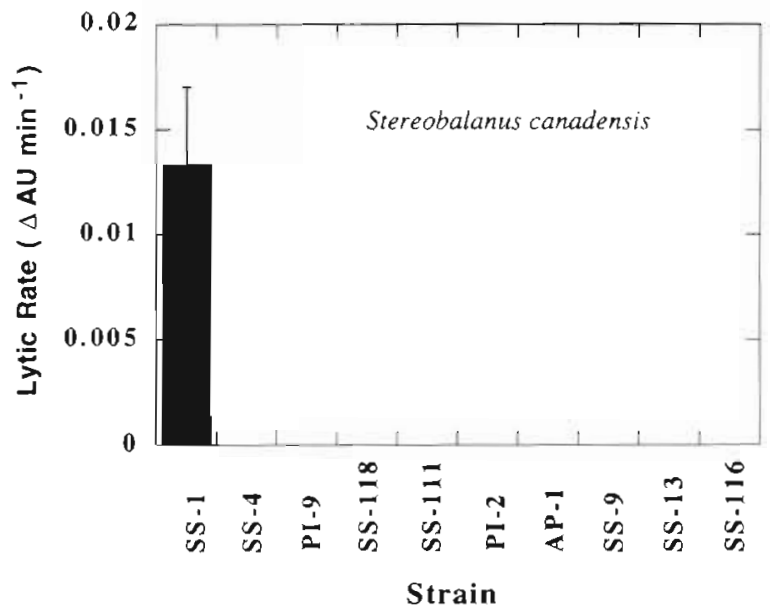

Fig. 1. Mean bacteriolytic rates $( \pm \mathrm{SEM}, \mathrm{n}=3$ ) of environmental isolates incubated with the digestive fluids of the deposit feeders (a) A. marina, (b) N. lobatus, (c) M. gracillima, (d) A. ornata, (e) $L$. tenuis, and (f) $S$. canadensis. $\triangle \mathrm{AU}$ : change in absorbance units. Note differences in $y$-axes scales

were roughly $10 \times$ greater than that of a holothuroid and of a hemichordate. We also observed the highest lytic capacities in polychaetes, regardless of bacterial strain, excepting those strains which were resistant in all cases.

In our study, bacterial strains differed significantly in susceptibility. This too is in agreement with earlier in vitro studies (Plante \& Shriver 1998). Field studies have also demonstrated compositional differences between the bacterial communities of ingested sediments and those of egesta (e.g. Findlay \& White 1983, Dobbs \& Guckert 1988, Duchene et al. 1988). Lysis of diverse sedimentary strains of bacteria by deposit-feeding macrofauna may occur at different rates, thus altering the composition of bacteria in feces and surrounding sediments. Differential digestion cannot clearly be concluded from the results of these previous field studies, however, since growth in the hindgut of the deposit feeders can be significant (Deming \& Colwell 1982, Plante et al. 1989) and may vary among bacterial strains. 
Table 3. Patterns of ranks of lytic susceptibility (see Table 2) were tested for independence. Rejection of the null indicates a tendency for similar rank order of lytic susceptibility of bacterial strains when incubated with the digestive fluids of various deposit feeders

\begin{tabular}{|ll|}
\hline Comparison & Independent? \\
\hline Arenicola marina vs Notomastus lobatus & $0.01<\mathrm{p}<0.025$ (reject) \\
Arenicola marina vs Microphiopholis gracillima & $\mathrm{p}<0.001$ (reject) \\
Arenicola marina vs Amphitrite ornata & $\mathrm{p}<0.001$ (reject) \\
Arenicola marina vs Leptosynapta tenuis & $0.025<\mathrm{p}<0.05$ (reject) \\
Arenicola marina vs Stereobalanus canadensis & $0.05<\mathrm{p}<0.10$ (accept) \\
Notomastus lobatus vs Microphiopholis gracillima & $0.001<\mathrm{p}<0.005$ (reject) \\
Notomastus lobatus vs Amphitrite ornata & $0.005<\mathrm{p}<0.01$ (reject) \\
Notomastus lobatus vs Leptosynapta tenuis & $0.05<\mathrm{p}<0.10$ (accept) \\
Notomastus lobatus vs Stereobalanus canadensis & $0.10<\mathrm{p}$ (accept) \\
Microphiopholis gracillima vs Amphitrite ornata & $0.005<\mathrm{p}<0.01$ (reject) \\
Microphiopholis gracillima vs Leptosynapta tenuis & $\mathrm{p}<0.001$ (reject) \\
Microphiopholis gracillima vs Stereobalanus canadensis & $0.05<\mathrm{p}<0.10$ (accept) \\
Amphitrite ornata vs Leptosynapta tenuis & $0.025<\mathrm{p}<0.05$ (reject) \\
Amphitrite ornata vs Stereobalanus canadensis & $0.05<\mathrm{p}<0.10$ (accept) \\
Leptosynapta tenuis vs Stereobalanus canadensis & $0.025<\mathrm{p}<0.05$ (reject) \\
\hline
\end{tabular}

Our isolates, it should be emphasized, were all actively growing (i.e. in log phase), whereas most bacteria in natural marine sediments are in an inactive phase and may be more (or less) susceptible to digestion. Clearly, our in vitro technique does not perfectly replicate the conditions of the gut, so these results reflect only relative susceptibilities. On the other hand, our assay provides a simple method to compare relative lytic susceptibilities among bacterial strains and to isolate the effect of midgut digestive fluids on ingested bacteria.

Trends in rank order of susceptibility of the 10 bacterial strains were generally similar across the 6 deposit-feeding taxa. Partitioning of the bacterial 'resource' was not apparent. Nearly half of the strains were resistant to lysis by the fluids of all deposit feeders tested. The remaining digestible strains showed fairly consistent trends in susceptibility so that the null hypothesis of no correlation among lytic susceptibility patterns was rejected in a majority of pairwise comparisons.

There were 2 exceptions to this finding. Three pairwise comparisons involving Stereobalanus canadensis could not be rejected at $\alpha=0.05$ (although 2 of these trended toward significance, i.e. $0.05<\mathrm{p}<0.10$ ). Presumably, this was due to the high number ( 9 of 10) of non-significant lytic rates, and therefore ties, for this species. That the lytic rate for this animal rarely differed from that of the PB control likely reflects quantitative rather than qualitative differences in lytic agents for $S$. canadensis versus those of the other animals tested. Gut fluids were difficult to collect in this small species and may well have been contaminated (diluted) with coelomic fluid. The end result would be a less potent digestive extract and a higher likelihood of non-significant lytic values (i.e. rates of 0 ).

The 1 additional exception involved the comparison between Notomastus lobatus and Leptosynapta tenuis. This may again have been due to low lytic capacities as these species ranked 4 and 5 in overall potency. The trend for lysis of susceptible bacteria was somewhat different for $N$. lobatus, however, in that it was the only species which did not digest SS-1 most efficiently. If these differences are real, the cause may involve the unique feeding mode of $N$. lobatus among this group of deposit feeders - it is the only animal studied which does not feed on surficial sediments, either directly or via rapid subduction.

Clearly, the universal resistance of the 4 strains AP1, SS-9, SS-13 and SS-116 contributes heavily to the rank correlation results. If these strains are removed for analysis (i.e. reducing $n$ to 6), however, much of the similarity in rank order among susceptible strains remains, with 9 of 15 comparisons significant at $\alpha=$ 0.10 and 2 of 15 at $\alpha=0.05$.

Our goal is to garner the ability to predict both the quantitative and qualitative responses of sedimentary bacterial communities to ingestion by deposit-feeders and subsequent gut passage. Earlier work (Dobbs \& Guckert 1988, Duchene et al. 1988) and the present study make clear that not all bacterial strains can be treated similarly with respect to their response to gut passage - some strains are lysed while others appear to be completely resistant. The present study does suggest, however, that at least qualitatively, these relationships are consistent among various deposit-feeding taxa so that model animals can represent well the guild as a whole in these types of study. 
Acknowledgements. We thank S. Hymel and 2 anonymous reviewers for constructive reviews of earlier drafts. We also thank S. Hymel for assistance with specimen collection. Financial support was provided by NSF grant OCE 95-04505. Contribution 141 of the Grice Marine Biological Laboratory, University of Charleston.

\section{LITERATURE CITED}

Carman KR, Thistle D (1985) Microbial food partitioning by three species of benthic copepods. Mar Biol 88:143-148

Deming JD, Colwell RR (1982) Barophilic growth of bacteria from intestinal tracts of deep-sea invertebrates. Microb Ecol 7:85-94

Dobbs FC, Guckert JB (1988) Microbial food resources of the macrofaunal-deposit feeder ptychodera bahamensis (Hemichordata: Enteropneusta). Mar Ecol Prog Ser 45: $127-136$

Duchene JC, Imbaud P, Delille D (1988) Assaciated bacterial microflora of a subantarctic polychaete worm Thelepus setosus. Arch Hydrobiol 112:221-231

Epstein S (1997) Microbial food webs in marine sediments. I. Trophic interactions and grazing rates in two tidal flat communities. Microb Ecol 34:188-198

Findlay $\mathrm{RH}$, White DC (1983) The effects of feeding by the sand dollar Mellita quinquiesperforata (Leske) on the benthic microbial community. J Exp Mar Biol Ecol 72: $25-41$

Editorial responsibility: John Dolan (Contributing Editor), Villefranche-sur-Mer, France
Gray JS, Johnson RM (1970) The bacteria of a sandy beach as an ecological factor affecting the interstitial gastrotrich Turbanella hyalina Schultze. J Exp Mar Biol Ecol 4: $119-133$

Grossmann S, Reichardt W (1991) Impact of Arenicola marina on bacteria in intertidal sediments. Mar Ecol Prog Ser 77 : $85-93$

Kemp PF (1990) The fate of benthic bacterial production. Rev Aquat Sci 2:109-124

King CH, Sanders RW, Schotts EB, Porter KG (1991) Differential survival of bacteria ingested by zooplankton from a stratified eutrophic lake. Limnol Oceanogr 36:829-845

Plante CJ, Jumars PA, Baross JA (1989) Rapid bacterial growth in the hindgut of a marine deposit feeder. Microb Ecol 18:29-44

Plante CJ, Mayer LM (1994) Distribution and efficiency of bacteriolysis in the gut of Arenicola marina and three additional deposit feeders. Mar Ecol Prog Ser 109:183-194

Plante CJ, Shriver A (1998) Differential lysis of sedimentary bacteria by Arenicola marina: examination of cell wall structure and exopolymeric capsules as correlates. $J \operatorname{Exp}$ Mar Biol Ecol (in press)

Prieur D, Mevel G, Nicolas JL, Plusquellac A, Vigneulle M (1990) Interactions between bivalve molluscs and bacteria in the marine environment. Oceanogr Mar Biol Annu Rev 28:277-352

Reiper M (1982) Feeding preferences of marine harpacticoid copepods for various species of bacteria. Mar Ecol Prog Ser 7:303-307

Submitted: July 8, 1997; Accepted: December 31, 1997 Proofs received from author(s): February 23, 1998 